\title{
Callus formation impedes adventitious rhizogenesis in air layers of broadleaved tree species
}

\author{
S. Singh, S.A. Ansari
}

Singh S., Ansari S.A., 2014. Callus formation impedes adventitious rhizogenesis in air layers of broadleaved tree species. Ann. For. Res. 57(1): 47-54, 2014.

Abstract. Callusing and root induction in air layering was evaluated aiming at evolution of procedure for mass clonal propagation of mature ortets of five tropical broadleaf species differing in their potential for adventitious root formation in shoot cuttings as: Anogiessus latifolia $<$ Boswellia serrata $<$ Dalbergia latifolia $<$ Gmelina arborea $<$ Dalbergia sissoo. Two experiments were conducted in rainy season during consecutive years; without application of growth regulators in the first year and with growth regulators $\left(\mathrm{T}_{1}\right.$ - water, $\mathrm{T}_{2}-100 \mathrm{ppm}$ indole-3-acetic acid, $\mathrm{T}_{3}-100 \mathrm{ppm}$ thiamine- $\mathrm{HCl}$ and $\mathrm{T} 4$-combination of $\mathrm{T}_{2}+\mathrm{T}_{3}$ ) in the next year. Air layered branches were detached from the trees to record percentage of alive airlayers, callusing and rooting (\%) as well as root number and root length. Response to air layering was found to be highly variable in five tree species but appeared to be feasible procedure for clonal propagation of mature ortets of B. serrata and D. sissoo with $100 \%$ (in auxin + thiamine treatment) and $83.3 \%$ (in auxin treatment) success, respectively. Maximum callusing (\%) was found in D. latifolia while no callusing was observed in $D$. sissoo, which is most easy-to-root among all five species. Callus formation impedes adventitious rhizogenesis in air layers as significant negative correlation of callusing (\%) and adventitious root formation was recorded in air layers of five tropical broadleaved tree species. Application of exogenous auxin alone or in combination with thiamine circumvents callusing to ensure direct development of roots for successful air layering. Keywords auxin, callusing, girdling, rooting, thiamine.

Authors. Sanjay Singh (sanjaysingh@lycos.com) - Forest Physiology and Molecular Biology Division, Institute of Forest Productivity, Aranyodaya, NH-23, Lalgutwa, Ranchi- 835303, India; S. A. Ansari - Institute of Forest Productivity, Aranyodaya, NH-23, Lalgutwa, Ranchi- 835303, India.

Manuscript received February 02, 2014; revised March 18, 2014; accepted May 30, 2014; online first June 13, 2014. 


\section{Introduction}

Clonal propagation of selected superior genotypes of tropical tree species is difficult owing to maturity related loss in adventitious root potential which constitutes a serious constraint, in their ex situ conservation and mass multiplication for sustainable use. Air layering involving production of in situ adventitious roots on girdled tree-shoots, which are subsequently detached and out planted, may serve as an effective mean of clonal propagation of such rooting recalcitrant woody perennials. The girdled shoots with continuous supply of water and mineral nutrients also obtain complex of endogenous biochemicals from apices and expanding leaves for root induction and differentiation leading to plantlet production. The procedure is simple, economical and space saving as no separate cloning area, controlled environmental conditions and intermittent misting are required. Air layering also offers the benefit of higher survival rates and faster rooting process.

Air layering technique has been successfully used to propagate some of the most recalcitrant forestry species such as Albizia procera (Ansari et al. 1998), Anogeissus pendula (Gupta et al. 1997), Elaeocarpus ganitrus (Bhojvaid \& Negi 2003) Osyris lanceolata (Mwang’ingo et al. 2006) and Prosopis cineraria (Solanki et al. 1986). However, on several instances in place of adventitious roots profuse callus formation occurs in the air layers even after ensuring optimal propagation conditions (moisture conservation and darkness) in air layers and treatment with growth regulators usually implicated in root induction and lapse of substantial time. In shoot cuttings of many species callus formation has been indicated as the precursor of root induction (Hartmann et al. 2010) but air layers behave in different manner showing callusing and adventitious rooting as independent physiological events (Sanjay Singh et al. 2004). Thus in the present study, callus and root induction in air-layering was evaluated aiming at evolution of procedure for mass clonal propagation of mature ortets of five tropical broadleaf species.

\section{Materials and methods}

Mature trees of five important tropical broadleaved species differing in their potential of adventitious root formation in shoot cuttings as: Anogiessus latifolia $<$ Boswellia serrata $<$ Dalbergia latifolia $<$ Gmelina arborea $<$ Dalbergia sissoo revealed in our earlier investigations (Ansari \& Sanjay Singh 2005) were used to conduct two experiments in consecutive years. In the first experiment on the onset of monsoon (rainy) season in the month of July three trees of each species in approximately 15 year old plantations were selected and air layered on 10 shoots ( i.e. 3 replications of 10 each) by removing bark, cambium and phloem with the help of a sharp knife. Moist Soilrite ${ }^{\circledR}$ (inert rooting media) was placed at the girdled area of the branch, which was subsequently covered with non-transparent black polythene sheet. No growth regulator treatment was provided to air layers.

In the next year, the influence of growth regulators was investigated. Four treatment viz., water $\left(\mathrm{T}_{1}\right), 100 \mathrm{ppm}$ indole-3-acetic acid $\left(\mathrm{T}_{2}\right), 100 \mathrm{ppm}$ thiamine-HCl $\left(\mathrm{T}_{3}\right)$ and combination of $T_{2}+T_{3}\left(T_{4}\right)$ were administered on the girdled area with the help of cotton before covering with soilrite and polythene sheet as described in the first experiment. Each treatment for a single species contained 40 layers in four trees (10 per tree) in randomized block design.

After 45 days the air layered branches were detached from the trees to record percentage of live air-layers, callusing and rooting (\%) as well as root number and maximum root length i.e. the length of longest adventitious root. The data were statistically analyzed employing analysis of variance (ANOVA), ' $F$ '-test to ascertain significance at $P \leq 0.05$ and least sig- 
nificant difference $\left(\mathrm{LSD}_{0.05}\right)$ values to separate means in different statistical groups (Gomez and Gomez 1984). The percentage data were transformed employing arc sine square root transformation prior to statistical analysis.

\section{Results}

A good number of air layered shoots remained alive after 45 days in first experiment where no exogenous treatment was employed (Table 1). Only D. sissoo and B. serrata responded positively to air layering with $68 \%$ and $52 \%$ adventitious rooting, respectively. Better root number and root length was recorded for $D$. sissoo than B. serrata. Formation of callus at the girdled areas was also observed especially in D. latifolia.

Significant interaction of species and treatments was recorded for live shoot (\%), callusing (\%) and rooting (\%) but not for root number and length. Combined dose resulted in significantly superior (100\%) rooting in $B$. serrata but in $D$. sissoo, IAA proved to be the best with $83 \%$ rooting (Table 2). Maximum

Table 1 Response of air layering in tree species without application of growth regulators

\begin{tabular}{llllll}
\hline Species & Live shoot (\%) & Callusing (\%) & Rooting (\%) & Root Number & Root length (cm) \\
\hline A. latifolia & 68.0 & 36.00 & 0.00 & - & - \\
B. serrata & 52.0 & 16.00 & 52.00 & 6.62 & 4.90 \\
D. latifolia & 68.0 & 58.00 & 0.00 & - & - \\
G. arborea & 44.0 & 24.00 & 0.00 & - & - \\
D. sissoo & 72.0 & 20.00 & 68.00 & 30.34 & 10.64 \\
LSD $_{0.05}$ & NS & 8.92 & 11.37 & 17.75 & 3.46 \\
\hline
\end{tabular}

Table 2 Interaction of tree species and growth regulator treatments on characteristics of air layering in Experiment 2 for the species; AL (A. latifolia), BS (B. serrata), DL (D. latifolia), GA (G. arborea) and DS (D. sissoo)

\begin{tabular}{|c|c|c|c|c|c|}
\hline \multirow[b]{2}{*}{ Interaction } & \multicolumn{5}{|c|}{ Characteristics } \\
\hline & $\begin{array}{l}\text { Live } \\
\text { Shoot (\%) }\end{array}$ & $\begin{array}{l}\text { Callusing } \\
\text { (\%) }\end{array}$ & Rooting (\%) & Root Number & $\begin{array}{l}\text { Root } \\
\text { Length }(\mathrm{cm})\end{array}$ \\
\hline$\overline{\mathrm{AL} \times \mathrm{T}_{1}}$ & 99.7 & 0.0 & 3.1 & 0.7 & 1.7 \\
\hline $\mathrm{BS} \mathrm{x} \mathrm{T}_{1}^{1}$ & 50.0 & 0.0 & 91.7 & 24.8 & 10.1 \\
\hline $\mathrm{DL} \times \mathrm{T}_{1}^{1}$ & 99.7 & 91.5 & 3.1 & 0.3 & 0.3 \\
\hline $\mathrm{GAXT}_{1}$ & 50.0 & 75.0 & 0.0 & 0.0 & 0.0 \\
\hline $\mathrm{DS}_{\mathrm{x}} \mathrm{T}_{1}^{1}$ & 75.0 & 0.0 & 75.0 & 30.1 & 13.9 \\
\hline $\mathrm{AL} \mathrm{x} \mathrm{T}_{2}^{1}$ & 99.7 & 32.9 & 11.7 & 2.0 & 3.0 \\
\hline $\mathrm{BS} \times \mathrm{T}_{2}^{2}$ & 75.0 & 3.1 & 91.7 & 23.6 & 8.8 \\
\hline $\mathrm{DL} \mathrm{x} \mathrm{T}_{2}$ & 100.0 & 0.0 & 0.0 & 0.0 & 0.0 \\
\hline $\mathrm{GAx} \mathrm{T}_{2}$ & 0.0 & 11.7 & 25.0 & 1.3 & 1.3 \\
\hline $\mathrm{DS} \mathrm{x} \mathrm{T}_{2}^{2}$ & 91.8 & 0.0 & 83.3 & 17.1 & 14.5 \\
\hline $\mathrm{AL} \mathrm{x} \mathrm{T}_{3}$ & 0.0 & 0.0 & 0.0 & 0.0 & 0.0 \\
\hline $\mathrm{BS}_{\mathrm{N} \mathrm{T}}^{3}$ & 75.0 & 11.7 & 91.7 & 8.2 & 7.2 \\
\hline $\mathrm{DL} \mathrm{x} \mathrm{T}_{2}^{3}$ & 100.0 & 32.9 & 3.1 & 0.3 & 0.3 \\
\hline $\mathrm{GA} \mathrm{x} \mathrm{T}_{3}$ & 58.7 & 99.7 & 0.0 & 0.0 & 0.0 \\
\hline DS $x \mathrm{~T}_{3}^{3}$ & 25.0 & 0.0 & 75.0 & 16.4 & 8.2 \\
\hline $\mathrm{AL} \mathrm{x} \mathrm{T}_{4}^{3}$ & 91.8 & 3.1 & 11.7 & 2.0 & 4.5 \\
\hline $\mathrm{BS} \times \mathrm{T}_{4}^{4}$ & 100.0 & 0.0 & 100.0 & 27.9 & 10.0 \\
\hline DL x T & 100.0 & 100.0 & 0.0 & 0.0 & 0.0 \\
\hline $\mathrm{GA} \times \mathrm{T}_{4}^{4}$ & 41.4 & 67.1 & 25.0 & 1.0 & 1.0 \\
\hline $\mathrm{DS} \times \mathrm{T}_{4}^{4}$ & 91.8 & 0.0 & 75.0 & 16.0 & 12.8 \\
\hline $\mathrm{LSD}_{005}{ }^{4}$ & 21.3 & 18.4 & 27.2 & NS & NS \\
\hline
\end{tabular}


callusing (\%) was found in D. latifolia while no callusing was observed in D. sissoo (Table 2).

In five species exogenous application of IAA alone or in combination with thiamine ensured better success in rooting of air layers. However, the influence of individual thiamine treatment or combined with IAA was more prominent for live shoot (\%) as observed in D. latifolia and G. arborea (Figure 1).

\section{Discussion}

Air layering technique is successful in propagating plants because the layered branch is not separated from the mother plant and, therefore, receives continuous supply of water and mineral nutrients through the xylem and remains alive (Hartmann et al. 2010) and intact shoots (with leaves) possibly synthesize some unknown auxillary substances which help in induction of adventitious roots (Sanjay Singh et al. 2004). Branch girdling also causes blockage in the acropetal and basipetal flow of photoassimilates in the phloem, causing an accumulation of several metabolites (organic compounds, carbohydrates, auxins, etc.) above this region (Alves-de Oliveira et al. 1999) that favors the formation of callus and development/ activation of adventitious root primordia to develop into roots (Sanjay Singh et al. 2004). In addition the absence of light in the area of root formation, use of substrates to provide continuous moisture, and moderate temperatures are factors that favor rooting in the girdling zone (Ramirez-Villalobos \& Urdaneta-Fernández 2004). Still different tree species differ in their potential of plantlet regeneration through air layering. In the present study also the response to air layering was found to be highly variable in five tree species. Two species D. sissoo and $B$. serrata appeared amenable for air layering even without growth regulator treatments but better rhizogeneis was in the later reflected in better root number and length.

Exogenous application of auxin-type growth regulators can speed up the rooting process in air layers (Hackett 1988, Bacarín et al. 1994, Rahman et al. 2000, Naz \& Aslam 2003). Auxins promote meristematic differentiation, and thus, their accumulation contributes to the formation of root primordia/callus in the girdling zone of the branch (Tchoundjeu et al. 2002). Improvement in the success of air layering occurred in all species in treated condition in our second experiment. The overall success of plantlet production was observed as $B$. serrata

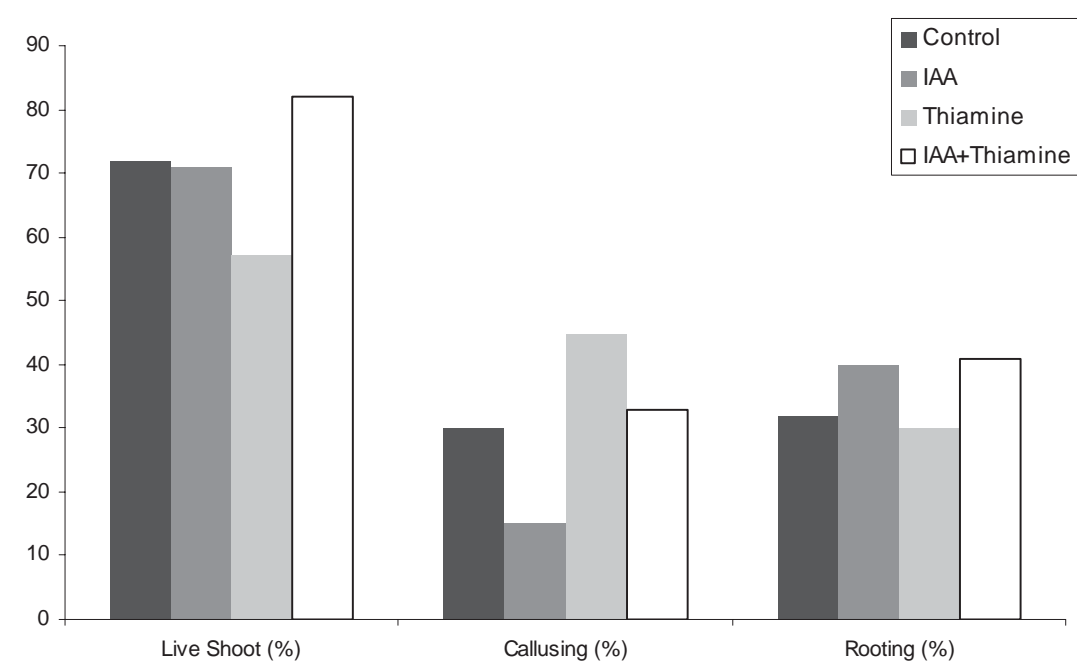

Figure 1 Percentage of live shoot, callusing and rooting in different treatment employed for air layers in five tropical trees 
$>$ D. sissoo $>$ G. arborea $=$ A. latifolia $>D$. latifolia. Combined dose of IAA and thiamine resulted in optimized rooting (100\%) in B. serrata. However, IAA alone was effective with $83 \%$ rooting in $D$. sissoo (Table 2). D. sissoo is most easy-to-root among all five species and no callusing was observed here while maximum callusing (\%) was found in D. latifolia a difficult to root species.

Callus development is common with wound healing where it appears as a thin layer around the wounded end of cuttings or girdled parts of air layers. This newly formed callus consisted of irregular unspecialized parenchymatous cells. The callus cells could further differentiate and form root primordia or serve as a protective layer for the formation of adventitious roots from other tissues of the layered branch (Colodi et al. 2008, Hartmann et al. 2010). Adventitious roots frequently emerged through the callus, leading to the belief that callus formation is essential for rooting because differentiation within callus led to formation of root initials (Hartmann et al. 2010). Adventitious roots are able to originate from callus tissue formed at the base of cutting, although connection with the main vascular system of these initials was extremely difficult (Davies et al. 1982). Skolidis et al. (1990) reported that, callus developed as a first step in process of root regeneration, followed by induction of root initials or primordias, indirect regeneration and root emergence in plum rootstock and cultivars. Kyonku \& Balta (2004) reported in tea leaf bud cuttings adventitious roots can initiate in callus, thus callus formation must precede root initiation. However, cuttings with excellent callus often failed to root, but many cuttings with poor callus developed root primordia and elongated. Evidently callus formation is an event that generally precedes adventitious rhizogenesis but callus and adventitious root formation appear to be independent phenomena in most plants. Simultaneous appearance of these tissues may happen because both are influenced by the same environmental factors
(Salisbury and Ross 1986, Burch \& McGraw 1996, Acosta et al. 2000, Colodi et al. 2008). Not much work has been conducted on the relationship of callusing and adventitious rooting in air layers but in case of shoot cuttings callus formation has been reported to hinder root formation process (Spethmann \& Hamza 1988) and it can be the consequence of unusual hormonal proportion due to higher exogenous treatments (Stefancic et al. 2005). Our findings reveal that callus formation impedes adventitious rhizogenesis in air layers as significant negative correlation of callusing (\%) and adventitious root formation in air layers of five tropical broadleaved tree species was recorded $(r=0.556, p<0.05 ; \mathrm{n}=20)$ (Figure 2).

In air layers profuse callusing usually occurs on the upper part of the girdled shoot indicating towards accumulation of photosynthates, auxins and auxiliary substances at abnormally high levels. Although IBA increases the elasticity of cell walls, accelerating division, excessive concentrations of the hormone may inhibit this process (Rahman et al. 2000). Exogenous auxin application in air layers during periods of active growth (high endogenous auxin levels) could raise hormone levels above the optimal concentrations, leading to a decrease in rooting (Moreira et al. 2009). A similar trend was obtained in air layers of M. rupestris, where concentrations higher than $1,500 \mathrm{mg}$ L-1 IBA resulted in a reduction of dry and fresh weights of the roots (Durán-Casas et al. 2013).

Both callusing and adventitious root formation occur in same time and space on shoot cuttings and/or girdled branches of air layers and apparently have similar growth requirements. Thus, it is possible that the processes compete for the available resources in plant. Appearance of callusing prior to adventitious rooting seems to be immediate response of the plant to heal the wounded part and not a perquisite for adventitious root induction. According to Sánchez et al. (2009), in air layers performed on guava (Psidium guajava) plants, with increasing concentrations of IBA $(2,000$, 
4,000, and 6,000 mg L-1), callus formation was reduced, and its formation was completely inhibited at the concentration of 6,000 mg L-1 IBA. Mishra \& Jaiswal (1993) also observed that only the air layers those treated with IBA exhibited rooting while other showed callusing. Thus, administration of exogenous auxin usually circumvents callusing to direct development of adventitious roots in air layers.

Adventitious root induction primarily depends on interaction between external environment and internal factors and interaction of the two. However, it is usual practice in forestry and horticulture to treat shoot cuttings with auxins which generally improve rooting. In addition a number of other biochemicals act either as auxin synergists to promote rhizogenesis or deterrent to rooting process (Fege and Brown 1984, Haissig 1984, Pythoud et al. 1986, Gasper \& Coumans 1987, Kling et al. 1988, Del Rio et al. 1991, Tchoundjeu \& Leakey 2000). Some reports have established augmenting role of auxins in rooting success in air layers too. For example exogenous application of IBA enhanced the root initiation and induced rooting in a shorter duration in Elaeocarpus ganitrus, Osyris lanceolata and some mangrove trees (Eganathan et al. 2000, Bhojvaid \& Negi 2003, Mwang'ingo et al. 2006). However, no effect of exogenous auxin was recorded in other species e. g. Cecropia obtusifolia, Inga feuillei (LaPierre 2001, Brennan \& Mudge 2004). Thiamine, with its established indispensability for in vitro growth and development of excised roots in many plants (Aberg 1961), may have a direct or indirect (as a synergist) role in rhizogenesis (Ansari \& Kumar 1994, Palanisamy et al. 1998, Ansari et al. 2002, Sanjay Singh et al. 2005). We observed in the five species under study that exogenous application of IAA alone or in combination with thiamine enhanced rooting of air layers. However, the influence of individual thiamine treatment or combined with IAA was more prominent for live shoot (\%) as observed in $D$. latifolia and $G$. arborea suggesting a synergistic role of thiamine rather than root initiating one, possibly by ensuring vigour of the air layers following wounding and removal of vital parts.

In conclusion, callusing may or may not precede adventitious rhizogenesis in air layers of tropical trees. Callusing and adventitious rooting appear to be independent phenomena

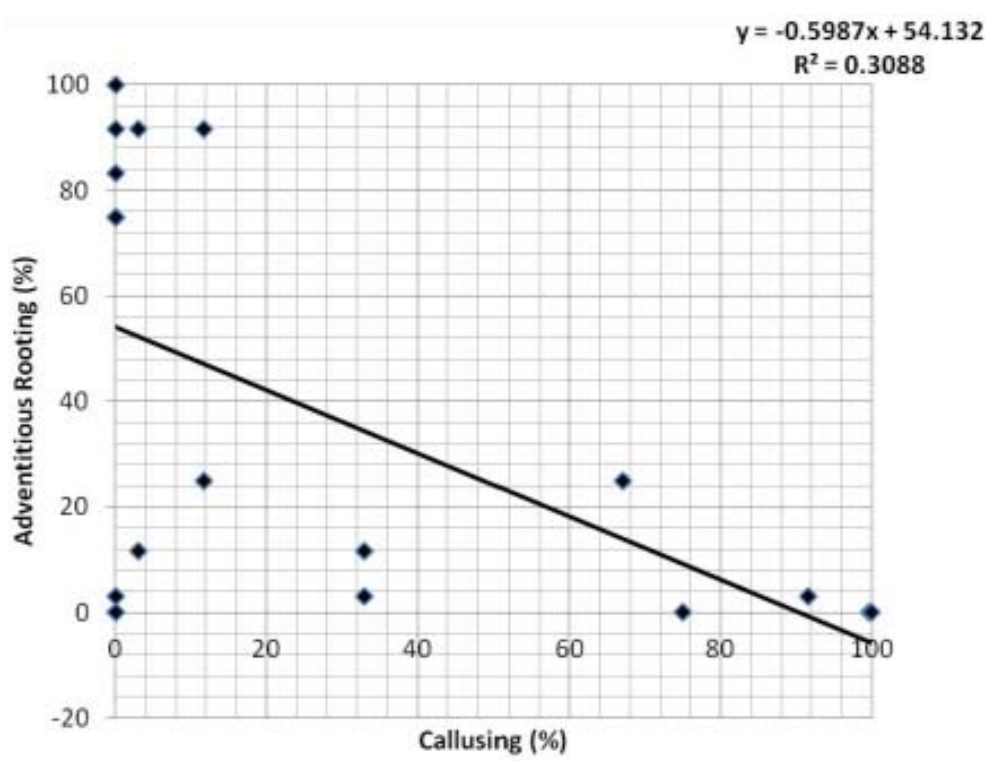

Figure 2 Linear regression analysis and specific correlation coefficient $\left(R^{2}\right)$ between callusing and adventitious rooting in five tropical broadleaved tree species 
occupying same time and space, competing for similar resources. Thus, callusing impedes adventitious root formation in air layers. Application of exogenous auxin alone or in combination with thiamine circumvents callusing to ensure direct development of roots for successful air layering.

\section{References}

Aberg B., 1961. Vitamins as growth factors in higher plants. Encyclopedia of Plant Physiology 14: 418-449.

Acosta E., Sánchez M., Ba-ón M., 2000. Auxinas (Auxins). In: Azcón-Bieto J., Talón M., (eds.), Fundamentosde fisiología vegetal [Fundamentals of Plant Physiology]. McGraw-Hill, Barcelona, Spain, pp. 305-323.

Alves-de Oliveira A., Carlos-Koller O., Villegas-Monter A., 1999. Vegetative propagation of 153 selection avocado (Persea sp.) by layering in container. Revista Chapingo, Serie Hort. 5: 221-225.

Ansari S.A., Kumar P., 1994. IAA synergism and vitamin B1 antagonism with calcium for induction and growth of adventitious roots in branch cuttings of Dalbergia sissoo Roxb. Indian Journal of Experimental Biology 32(6): 441-442.

Ansari S.A., Kumar P., Mandal A.K., 1998. An air-layering method for clonal propagation of Albizia procera. Indian Forester 124(5): 354-356.

Ansari S.A., Sanjay Singh, 2005. Studies on differential adventitious rooting response vis-à-vis clonal propagation of economically important forestry species. Tropical Forest Research Institute, Jabalpur (India), 73 p.

Ansari S.A., Sharma S., Pant N.C., Mandal A.K., 2002. Synergism between IBA and thiamine for induction and growth of adventitious roots in Tectona grandis. Journal of Sustainable Forestry 15(4): 99-112. DOI: 10.1300/ J091v15n04_05.

Bacarin, M.A., Benincasa M.M.P., Andrade V.M.M., Pereira F.M., 1994. Rooting of stem cuttings of guava Psidium guajava L.: effect of indole butyric acid IBA on root initiation. Cientifica Jaboticabal 22(1): 71-79.

Bhojvaid P.P., Negi S., 2003. Propagation of Elaeocarpus ganitrus by air layering. Indian Forester 129(10): 11851191.

Brennan E.B., Mudge K.W., 1998. Vegetative propagation of Inga feuillei from shoot cuttings and air layering. New Forests 15(1): 37-51. DOI: 10.1023/ A:1006594207046.

Burch L., McGraw B., 1996. Citoquininas. In: Azcón-Bieto J., Talón M., (eds.), Fundamentals of plant physiology. McGraw-Hill, Barcelona, Spain, pp. 319-326.

Colodi F., Ramos N., Zuffellato-Ribas K., Ribas L., Koehler H., 2008. Vegetative propagation of guaco with added naphthalene acetic acid. Scientia Agraria 9(1):
95-98.

Davies F.T.Jr., Lazarte J.E., Joiner J.N., 1982. In initiation and development of roots in juvenile and mature leaf bud cuttigs of Ficus pumila L. American Journal of Botany 69(5): 804-811. DOI: 10.2307/2442971.

Del Rio E., Rallo N.L., Caballero J.M., 1991. Effects of carbohydrate content on the seasonal rooting of vegetative and reproductive cuttings of olive. Journal of Horticultural Science 66(3): 301-309.

Durán-Casas S., Veloza-Suan C., Magnitskiy S., Orlando Lanchero H., 2013. Evaluation of uva camarona ( $M a-$ cleania rupestris Kunth A.C. Smith) propagation with air layering. Agronomía Colombiana 31(1): 18-26.

Eganathan P., Srinivasa Rao C., Anand A., 2000. Vegetative propagation of three mangrove tree species by cuttings and air layering. Wetlands Ecology and Management 8(4): 281-286. DOI: 10.1023/A:1008481222718.

Fege A., Brown G., 1984. Carbohydrate distribution in dormant Populus shoots and hardwood cuttings. Forest Science 30(4): 999-1010.

Gasper T., Coumans M., 1988. Root formation. In: Bonga J.M., Durzan D.J., (eds.), Cell and Tissue Culture in Forestry. Martinus Nijofff Pub., Dordrecht, pp. 202217.

Gomez K.A., Gomez A.A., 1984. Statistical procedures for agricultural research. John Wiley and Sons Inc., Singapore, $680 \mathrm{p}$.

Gupta V.K., Kumar R.V., Dattta A., Solanki K.R., 1997. Vegetative propagation in Anogeissus pendula. Range Management and Agroforestry 18(1): 85-90.

Hackett W.P., 1988. Donor plant maturation and adventitious rootformation. In: Davis T.D., Hassing B.E., Sankhla N., (eds.). Adventitious root formation in cuttings: Advances in Plant Sciences Series. Dioscorides Press, Portland, pp. 11-28.

Haissig B.E., 1984. Carbohydrate accumulation and partitioning in Pinus banksiana seedlings and seedling cuttings. Plant Physiology 61: 13-19. DOI: 10.1111/j.13993054.1984.tb06093.x.

Hartmann H., Kester D., Davies F., Geneve R., 2010. Plant propagation: Principles and Practices. Prentice Hall, Upper Saddle River, NJ, 880 p.

Kling G.J., Meyer M.M.Jr., Siegler D., 1988. Rooting cofactors in five Acer species. Journal of the American Society for Horticultural Science113: 252-257.

Koyuncu F., Balta F., 2004. Adventitious root formation in leaf-bud cuttings of tea (Camellia sinensis L.). Pakistan Journal of Botany 36(4): 763-768.

La Pierre L.M., 2001.Vegetative propagation of Cecropia obtusifolia (Cecropiaceae). Revista de Biología Tropical 49(3-4): 973-976.

Misra K.K., Jaiswal H.R., 1993. Propagation of Anthocephalus chinensis (LAM.) R. Rich Ex. Walp. by air layering with the aid of indole butyric acid. Indian Forester 119(7): 587-589.

Moreira O., Martins J., Silva L., Moura M., 2009. Propagation of the endangered Azorean cherry Prunus azorica using stem cuttings and air layering. ARHIPÉLAGO, 
Ciências Biológicas e Marinhes 26: 9-14.

Mwang'ingo P., Teklehaimanot L.Z., Lulandala L.L., Maliondo S.M., 2006. Propagating Osyris lanceolata (African sandalwood) through air layering: Its potential and limitation in Tanzania. The Southern African Forestry Journal 207: 7-13. DOI: 10.2989/1029592060950524.

Naz S., Aslam M., 2003. Effect of different concentrations ofindole butyric acid (IBA) and age of shoot on air layering ofmango (Mangifera indica Linn.). Journal of Research Science 14(2): 193-198.

Palanisamy K., Ansari S.A., Kumar P., Gupta B.N., 1998. Adventitious rooting in shoot cuttings of Azadirachta indica and Pongamia pinnata. New Forests 16(1): 8188. DOI: 10.1023/A:1006586603388.

Pythoud F., Buchala A.J., Schmid A., 1986. Adventitious root formation in green cuttings of Populus tremula: characterization of the effect of vitamin D3 and indolebutyric acid. Plant Physiology 68: 93-99. DOI: 10.1111/ j.1399-3054.1986.tb06601.x.

Rahman N., Hussain I., Imran M., Jan T., Awan A., 2000. Effect of different concentrations of IBA on rooting of litchi (Litchi chinensis) in air layering. Pakistan Journal of Biological Sciences 3: 330-331. DOI: 10.3923/ pjbs.2000.330.331.

Ramírez Villalobos, M. y A. Urdaneta-Fernández, 2004. Efecto del ácido naftalenacético y de diferentes sustratos sobre el enraizamiento de acodos aéreos del guayabo (Psidium guajava L.). Revista de la Facultad de Agronomía (LUZ). 21 (Supl. 1): 28-34.

Salisbury F., Ross C., 1986. Plant Physiology. CBS Pub., New Delhi, India, 540 p.

Sánchez A., Suárez E., González M., Amaya Y., Colmenares C., Ortega J., 2009. Effect of indole butyric acid on rooting of air layers of guava (Psidium guajava L.) in the municipality Baralt, Venezuela. Evaluación preliminar. Revista Científica UDO Agrícola 9: 113-120.

Sanjay Singh, Kumar P., Ansari S.A., 2005. Clonal propagation of teak (Tectona grandis) by composite treatment of auxin with thiamine. Indian Journal of Forestry 28(2): 108-111.

Sanjay Singh, Kumar P., Mandal A.K., Ansari S.A., 2004. Air-layering of trees with differential adventitious rooting response. Indian Forester 130 (3): 318-322.

Skolidis K., Hartman W., Stosser R., 1990. Histological examination of root formation on wooden plug of documents and plum varieties. Gartenbauwissenschaft 55(4): 151-154.

Solanki K.R., Kackar N.L., Jindal S.K., 1986. Air layering in Prosopis cineraria (L.) MacBride. Indian Forester 112(3): 202-207.

Spethmann W., Hamzah A., 1988. Growth hormone induced root system types in cuttings of some broad leaved tree species. Acta Horticulturae 226: 601-605.

Stefancic M., Stamper F., Osterc G., 2005. Influence of IAA and IBA on root development and quality of Prunus 'GiSelA 5' leafy cuttings. Hortscience 40(7): 2052-2055.

Tchoundjeu Z., Avana M., Leakey R.R.B, Simons A., Asaah E., Duguma B., Bell J., 2002. Vegetative propagation of Prunus africana: effects of rooting medium, auxin concentrations and leaf area. Agroforestry Systems 54(3): 183-192. DOI: 10.1023/A:1016049004139.

Tchoundjeu Z., Leakey R.R.B., 2000. Vegetative propagation of Khaya ivorensis (African mahogany): effects of stockplant flushing cycle, auxin and leaf area on carbohydrate and nutrient dynamics of cuttings. Journal of Tropical Forest Science 12: 77-91. 